\title{
PENGEMBANGAN MODUL BERBASIS PENEMUAN TERBIMBING PADA MATA KULIAH GEOMETRI TRANSFORMASI
}

\author{
Rina Febriana \\ Prodi Pendidikan Matematika Universitas Cokrominoto Yogyakarta \\ Email: rinafebriana0502@gmail.com
}

\begin{abstract}
Abstrak
Berdasarkan hasil observasi proses pembelajaran masih menggunakan metode konvensional dan buku teks yang dipakai dalam proses perkuliahan belum mampu menggiring untuk menemukan sebuah konsep.Tujuan penelitian adalah untuk merancang modul berbasis penemuan terbimbing pada mata kuliah geometri transformasi di STKIP PGRI Sumatera Barat. Jenis penelitian ini adalah penelitian pengembangan dengan menggunakan model Plomp yang terdiri atas 3 fase yaitu preliminary research, prototyping phase, dan assessment phase (Plomp,2013: 19). Tahap preliminary research terdiri dari wawancara kepada siswa dan guru, analisis silabus, dan analisis buku teks Tahap prototyping phase yaitu merancang sistematika dan struktur modul, pengembangan prototipe, tinjauan ahli. Hasil yang diperoleh pada tahap preliminary research adalah bersarkan wawancara dengan dosen dan mahasiswa kurang memahami konsep dasar geometri dan kurang mampu dalam membuktikan dalil, Pada analisis silabus dan literatur yang dilakukan adalah bahwa materi yang diajarkan sesuai dengan silabus. Hasil validitas modul dari para ahli menunjukkan bahwa modul berbasis penemuan terbimbing pada kategori cukup valid.
\end{abstract}

Kata Kunci: analisis, modul, penelitian pengembangan, geometri transformasi

\section{PENDAHULUAN}

Sampe saat ini masih sangat jarang penelitian yang membahas tentang modul geometri, beberapa penelitian yang membahas modul diantaranya adalah (Tiernan 2016) modul kewirausahaan digunakan dalam pembelajaran untuk mendapatkan kondisi yang paling nyata dalam perusahaan. Selanjutnya (Gibbs 2010, Brown, Rich et al. 2014) modul hendaknya dirancang untuk meningkatkan kemampuan dalam pengambilan keputusan manajerial, memperbanyak kuliah secara praktik dan menciptakan keterlibatan mahasiswa yang semakin besar. (Hodgkinson 2000, Tariq, Scott et al. 2004) mengembangkan modul ke dalam matrik kompetensi keterampilan, untuk meningkatkan pembelajaran, lebih ditekankan perbaikan modul pada peningkatan keterampilan yang ingin dicapai. Modul disusun berdasaskan hasil penelitian dosen sebagai bahan ajar berbasis riset (Emmitt 2005)

Penelitian lain menyebutkan hasil yang berbeda (Grattan, Brown et al. 1998) menjelaskan bahwa siswa yang mendapatkan modul dan tidak mendapatkan modul tetap memiliki peningkatan keterampilan, sehingga tidak ada perbedaan antara mahasiswa yang mendapatkan modul, dengan mahasiswa yang tidak mendapatkan modul, namun lingkungan belajar yang mendorong siswa dalam mengembangkan keterampilan komunikasi dan teknologi informasi. (Palihawadana and Holmes 1999, Emmitt 2005) mengevaluasi modul maupun tutor, hasil menunjukkan bahwa sebagian besar siswa mengevaluasi positif terhadap modul dan tutor, serta merekomendasikan kepada kelas lain untuk menggunakan modul tersebut dalam pembelajaran, penelitian 
ini lebih memfokuskan pada bagaimana modul diperbaiki sesuai dengan masukan oleh mahasiswa.

Modul sangat bermanfaat bagi mahasiswa dengan pencapaian kinerja yang rendah, modul disusun dengan menerapkan pola langkah dan strategi pengajaran agar kinerja mahasiswa rendah dapat meningkat lebih baik untuk berkinerja tinggi. Partisipasi di kelas memiliki dampak positif terhadap kinerja, partisipasi yang berbeda antar mahasiswa memberikan dampak pada kinerja yang berbeda antar mahasiswa, dosen diharapkan memotivasi mahasiswa untuk meningkatkan kehadiran dalam kelas, menyusun modul meningkatkan keterlibatan siswa sehingga mahasiswa lebih proaktif dan antusian dalam kelas serta prestasi akademik meningkat (Pani and Kishore 2016)

Modul transformasi geometri sangat dibutuhkan mahasiswa dalam mempelajari geseran, setengah putaran, pencerminan, putaran, pencerminan geser, dan komposisi dua transformasi, dengan adanya modul, diharapkan motivasi mahasiswa untuk belajar mandiri akan meningkat, dan kemampuan berfikir mahasiswa akan semakin baik. (Kirby 2007, Bridge, Hegarty et al. 2010, Tiernan 2016) menyebutkan bahwa dampak dari modul adalah meningkatkan mahasiswa untuk berfikir dan bertindak secara kreatif dan inovatif dalam segala hal, modul kewirausahaan disusun dengan pendekatan berbeda, teori, studi kasus, diskusi, aktivitas berbasis pengalaman, dan mahasiswa diberikan tugas dengan tujuan untuk meningkatkan kemampuan mahasiswa calon pendidik dalam berfikir kreatif, mampu memecahkan masalah, dan mempresentasikan gagasan baru.

Modul mata kuliah transformasi geometri menggunakan pendekatan penemuan terbimbing diharapkan mahasiswa dapat mengembangkan kemampuan berfikir untuk dapat mengambil kesimpulan dari hasil observasi, mengembangkan kemampuan untuk bertanya dan menjawab pertanyaan, mengembangkan keahlian dan kepercayaan diri, dan menyedarkan apa yang telah dialami, memproses pengelaman belajar yang berbeda menjadi bermakna dalam kehidupan nyata, sehingga mahasiswa akan lebih produktif, meningkatnya kemampuan analisis, dan berfikir kritis.

\section{METODE PENELITIAN}

Model pengembangan dalam penelitian ini mengikuti model umum desain penelitian umum menurut (Fauzan, Plomp et al. 2013) yang terdiri atas 3 fase yaitu preliminary research, prototyping phase, dan assessment phase. Tahap preliminary research merupakan tahap yang menekankan pada validitas isi. Hal ini terlihat dari analisis masalah dan studi literatur. Pada tahap kedua yaitu tahap prototyping phase pengembangan lebih difokuskan pada konsistensi (validitas konstruk) dan praktikalitas, selanjutnya mengutamakan praktikalitas dan secara bertahap menuju efisiensi, penelitian ini baru sampai pada tahap prototyping phase.

Instrumen pengumpulan data yang digunakan pada penelitian ini adalah Instrumen pada Tahap Prototyping Phase menggunakan lembar validasi, lembar validasi digunakan untuk mengetahui valid atau tidaknya modul pada mata kuliah geometri 
trasnformasi dengan pendekatan penemuan terbimbing. Lembar validasi modul berisi aspek-aspek yang telah dirumuskan, dan skala penilaian pada lembaran validasi menggunakan skala Likert.

Tabel 1. Kisi-kisi Lembar Validasi dengan Pendekatan Penemuan Terbimbing

\begin{tabular}{|c|c|c|}
\hline $\mathrm{No}$ & Aspek & Tujuan \\
\hline (1) & (2) & (3) \\
\hline 1 & Kelayakan Isi & $\begin{array}{l}\text { 1. Untuk melihat kesesuaian materi dengan } \\
\text { kompetensi yang dicapai } \\
\text { 2. Untuk melihat kebenaran substansi materi } \\
\text { pembelajaran }\end{array}$ \\
\hline 2 & Penyajian Materi & $\begin{array}{l}\text { 1.Untuk melihat kesesuaian penyajian modul } \\
\text { dengan unsur-unsur Modul } \\
\text { 2.Untuk melihat kesesuaian penyajian materi } \\
\text { dan kekonsistenan penyajian materi } \\
\text { berdasarkan komponen dengan pendekatan } \\
\text { penemuan terbimbing }\end{array}$ \\
\hline 3 & $\begin{array}{ll}\text { Bahasa dan } \\
\text { Keterbacaan }\end{array}$ & $\begin{array}{l}\text { 1. Untuk melihat penggunaan bahasa Indonesia } \\
\text { yang baik dan benar } \\
\text { 2. Untuk melihat kejelasan informas }\end{array}$ \\
\hline 4 & Kegrafikan & $\begin{array}{l}\text { 1. Untuk melihat ukuran atau format modul, } \\
\text { design dan kualitas modul }\end{array}$ \\
\hline
\end{tabular}

Sumber: dimodifikasi dari panduan pengembangan bahan ajar Depdiknas (2008:28)

\section{HASIL DAN PEMBAHASAN}

Tahap ini dilakukan untuk melihat gambaran kondisi di lapangan yang berkaitan dengan proses perkuliahan geometri transormasi di STKIP PGRI Sumatera Barat. Pada tahap ini dilakukan langkah-langkah seperti analisis silabus, analisis buku teks, analisis literatur, analisis karakteristik mahasiswa dan wawancara dengan teman sejawat. Hasil yang diperoleh pada masing-masing langkah tersebut adalah sebagai berikut.

\section{1) Analisis Silabus}

Pada tahap ini dilakukan analisis silabus pada mata kuliah geometri transformasi di Program Studi Pendidikan Matematika STKIP PGRI Sumatera Barat. Analisis silabus 
dilakukan untuk melihat apakah materi yang diajarkan sudah sesuai dengan kompetensi yang diharapkan.

Berdasarkan hasil dari analisis silabus diketahui bahwa Standar Kompetensi (SK) dari mata kuliah ini adalah mahasiswa Mampu menguasai konsep teoritis, struktur, dan pola pikir keilmuan matematika tentang geometri transformasi di bidang datar yang meliputi transformasi, translasi, isometri, setengah putaran, refleksi, putaran, refleksi geser dan kesebangunan serta dapat menggunakannya dalam memecahkan berbagai macam masalah.

\section{2). Analisis Buku Teks}

Analisis buku teks yang dilakukan bertujuan untuk melihat apakah isi buku sudah sesuai dengan kompetensi dalam silabus. Buku teks yang dianalisis adalah buku teks yang selama ini digunakan dalam perkuliahan geometri transformasi yang merupakan buku wajib adalah B. Susanta (1990). Geometri Transformasi. FMIPA Universitas Gajah Mada: Yogyakarta dan Rawuh. 1992. Geometri Transformasi. Dept. P dan K: Bandung.

Berdasarkan analisis yang telah dilakukan diperoleh hasil bahwa materi yang ada didalam buku tersebut adalah transformasi, translasi, isometri, setengah putaran, refleksi, putaran, refleksi geser dan kesebangunan serta dapat menggunakannya dalam memecahkan berbagai macam masalah.Penyajian materi pada buku teks sulit dipahami oleh mahasiswa. Penyajian materi tidak mampu menuntun mahasiswa dalam menemukan sebuah konsep .

.Berdasarkan hasil analisis yang diuraikan tersebut, maka pengembangan modul dilakukan dengan mengacu pada silabus yang ada. Penyajian modul dirancang sedemikian rupa sehingga dapat memfasilitasi mahasiswa untuk bisa menemukan 
konsep secara mandiri. Oleh karena itu, pengembangan modul didesign dengan basis penemuan terbimbing.

\section{3). Analisis Literatur}

Kegiatan menganalisis literatur merupakan kegiatan yang dilakukan untuk mengumpulkan bahan yang terkait dengan perancangan modul. Yang merupakan ciri khas dari modul yang akan dikemangkan ini adalah berbasis penemuan terbimbing. Penemuan terbimbing merupakan metode yang mendorong mahasiswa unruk berfikir sendiri, menganalisis sendiri sehingga dapat menemukan prinsip dari bahan atau data yang telah disediakan oleh dosen. Dalam menggunakan metode penemuan terbimbing peran dosen adalah sebagai menyatakan persolan, kemudian membimbing mahasiswa untuk menemukan penyelesaian dari persoalan itu dengan petunjuk atau arahan yang ada didalam modul tersebut. Mahasiswa mengikuti petunjuk yang ada dalam modul tersebut (Widiharto, 2004: 5)

\section{4). Analisis Karakteristik Mahasiswa}

Berdasarkan hasil pengamatan yang telah dilakukan, diketahui bahwa mahasiswa STKIP PGRI Sumatera Barat Program Studi Pendidikan Matematika, cara belajar dan motivasi mahasiswa dalam perkuliahan geometri transformasi masih kurang. Hal ini disebakan oleh buku teks yang digunakan selama ini belum mampu menjadi sumber belajar yang memfasilitasi mahasiswa untukmenemukan konsep secara mandiri.

Berdasarkan hasil pengamatan yang telah dilakukan dalam proses perkuliahan selama ini, diketahui bahwa secara garis besar karakteristik cara belajar mahasiswa dalam perkuliahan geometri transformasi adalah sebagai berikut; 1)Mahasiswa mudah lupa terhadap konsep yang dipelajarinya jika mahasiswa tersebut tidak dilibatkan dalam proses membangun pemahaman konsep seperti melakukan penemuan-penemuan. Sumber belajar yang dipakai selama ini belum mampu melibatkan mahasiswa secara 
aktif, 2) Mahasiswa kesulitan belajar mandiri dengan sumber belajar yang terbatas, 3) Mahasiswa yang termotivasi belajar dan mengerjakan tugas hanyalah mahasiswa yang berkemampuan tinggi, 4) Sumber belajar yang disediakan oleh ruang baca Prodi Pendidikan matematika dan perpustakaan memiliki jumlah yang terbatas. Keterbatasan ini menyebabkan hanya beberapa orang saja yang memiliki sumber belajar. Hal ini tentu saja dapat menghambat terjadinya proses perkuliahan yang kondusif.

Hasil analisis dari karakteristik mahasiswa STKIP PGRI Sumatera Barat dapat melatarbelakangi perlunya dilakukan pengembangan suatu Modul. Pengembangan modul berbasis penemuan terbimbing dapat mendorong mahasiswa untuk berfikir sendiri, menganalisis sendiri sehingga dapat menemukan prinsip dari bahan atau data yang telah disediakan oleh dosen.

\section{5). Wawancara dengan Teman Sejawat}

Setelah menganalisis buku rujukan geometri transformasi, kegiatan selanjutnya adalah wawancara dengan teman sejawat. Wawancara dengan teman sejawat bertujuan untuk mengetahui masalah/ hambatan apa saja yang dihadapi di lapangan sehubungan dengan perkuliahan geometri transformasi. Berdasarkan hasil wawancara, diketahui bahwa selama ini proses perkuliahan geometri transformasi hanya mengacu pada dua buku teks dan menggunakan metode ceramah. Mahasiswa banyak bergantung pada penjelasan Dosen dalam memahami materi. Ini berarti, mahasiswa belum mampu untuk belajar mandiri. Oleh karena itu, diperlukan suatu bahan ajar yang praktis dari dosen dengan metode pengembangan tertentu sehingga mampu memfasilitasi mahasiswa untuk belajar secara mandiri. Dengan demikian, mahasiswa tidak terlalu banyak membutuhkan bantuan dosen dalam perkuliahan

Bahan ajar berupa modul berbasis penemuan terbimbing ini dirancang untuk mata kuliah geometri transformasi. Modul yang dirancang ini terdiri dari tujuh kegiatan yaitu fungsi dan transformasi, transformasi, isometri, translasi, setengah putaran,rotasi dan pencerminan geser. Modul ini dirancang untuk satu semester. Bentuk modul di 
design berdasarkan karakterirstik penemuan terbimbing, yakni mahasiswa dibimbing untuk menemukan suatu konsep. Hasil rancangan modul berbasis penemuan terbimbing adalah sebagai berikut:

1) Cover

Cover pada modul berbasis penemuan terbimbing sudah mencerminkan isi, dengan menampilkan gambar yang berkaitan dengan matri pada mata kuliah geometri transformasi tersebut.

2) Setiap modul memuat kompetensi utama, kompetensi khusus dan petunjuk belajar, hal ini digunakan untuk memudahkan mahasiswa menggunakan modul seperti pada gambar 4 .

Setiap kegiatan pada modul memuat kompetensi utama, kompetensi khusus dan petunjuk penggunaan modul, hal ini bertujuan supaya mahasiswa mengetahui tujuan utama dari pembelajaran tersebut dan memudahkan mahasiswa dalam menggunakan modul tersebut

\section{3) Uraian Materi}

Modul didalam uraian materi ini berisi tentang materi dan contoh soal. Didalam penjelasan materi masih ada yang kosong yang akan di isi oleh mahasiswa untuk menenukan suatu konsep.

4) Soal Latihan

Soal latihan yang ada palam modul ini bertujuan untuk melihat pemahaman mahasiswa terhadap materi yang telah dipelajari.

Pada tahap pengembangan untuk penelitian tahun pertama ini baru samapi pada tahap validasi modul. Untuk mendapatkan modul yang valid, maka dilakukan proses validasi oleh beberapa pakar yaitu pada pakar geometri transformasi yang terdiri dari 2 
orang validator. Validasi yang dilakukan pada tahap ini hanya validitas isi dan konstruks. Aspek yang diamati adalah : 1) Aspek kelayakan isi, 2) Aspek penyajian, 3) Kebahasaan dan 4) Kegrafikan. Hasil validasi dapat dilihat pada tabel 2:

Tabel 2 : Hasil Validasi

\begin{tabular}{|c|l|l|l|}
\hline No & \multicolumn{1}{|c|}{ Aspek } & \multicolumn{1}{c|}{ Rata-rata } & \multicolumn{1}{c|}{ Kategori } \\
\hline 1 & Kelayakan isi & 2,85 & Valid \\
\hline 2 & Penyajian & 2,38 & Cukup Valid \\
\hline 3 & Kebahasaan & 2,87 & Valid \\
\hline 4 & Kegrafikan & 2,31 & Cukup Valid \\
\hline \multicolumn{2}{r}{ Rerata } & 2,58 & Cukup Valid \\
\hline
\end{tabular}

Hasil pada Tabel 2 validasi modul menunjukkan bahwa nilai rata-tata asek sudah termasuk kategori cukup valid, dengan rerata secara umum 2,58. Produk ini akan dilanjutkan pada proses validasi untuk mendapatkan modul yang valid dengan melakukan perbaikan terhadap modul tersebut.

Selama poses validasi, validator memberikan saran dan masukan untu mendapatkan modul yang berkualitas baik. Adapun saran dari validator dapat dilihat pada tabel 3:

Tabel 3: Saran dari Validator

\begin{tabular}{|l|l|l|}
\hline No & \multicolumn{1}{|c|}{ Aspek } & \multicolumn{1}{|c|}{ Saran } \\
\hline 1 & Penyajian & $\begin{array}{l}\text { Pada aspek penyajian belum memberikan } \\
\text { gambaran unsur penemuan terbimbing } \\
\text { didalamnya, dan uraian materi masih banyak } \\
\text { juga terdapat kekurangan didalamnya dan } \\
\text { untuk soal latihan soal diperbanyak. }\end{array}$ \\
\hline 2 & Aspek Bahasa & $\begin{array}{l}\text { Pada aspek bahasa jangan menggunakn makna } \\
\text { ganda. Gunakan bahasa yang mudah dipahami } \\
\text { oleh mahasiswa dan perhatikan EYD. }\end{array}$ \\
\hline
\end{tabular}

Penelitian pengembangan ini menghasilkan produk berupa Modul berbasis Penemuan Terbimbing. Modul ini memfasilitasi proses belajar mandiri bagi mahasiswa. Setelah Modul selesai dirancang, selanjutnya dilakukan uji validitas. Hasil validasi menunjukkan bahwa validitas Modul berbasis Penemuan Terbimbing.untuk perkuliahan Geometri Transformasi pada mahasiswa Program Studi Pendidikan Matematika STKIP 
PGRI Sumatera termasuk dalam kriteria cukup valid. Ini merupakan tahap validasi awal.

Modul berbasis Penemuan Terbimbing untuk perkuliahan Geometri Transformasi sudah cukup valid berdasarkan hasil penilaian dari validator. Materi yang disajikan telah sesuai dengan kompetensi yang ingin dicapai. Materi telah disajikan dengan urutan yang sistematis dan dirumuskan berdasarkan pada unsur-unsur pembelajaran Kontekstual sehingga mampu memfasilitasi mahasiswa untuk belajar mandiri dan menggiring mahasiswa dalam menemukan konsep. Materi yang disajikan pada Modul telah memberikan kesempatan kepada mahasiswa untuk menemukan konsep. Penemuan sebagai metode mengajar merupakan penemuan yang dilakukan oleh mahasiswa. Ini berarti, dalam proses pembelajarannya siswa/ mahasiswa menemukan sendiri sesuatu hal yang baru namun sudah diketahui oleh orang lain (guru/ dosen). Konsep-konsep yang diuraikan pada materi menggiring mahasiswa untuk menemukan konsep. Hal ini terbukti mampu meningkatkan pemahaman mahasiswa terhadap konsep yang dipelajarinya. Selain itu, contoh soal, dan latihan mandiri relevan dengan materi yang disajikan sehingga mahasiswa tidak menemukan kendala yang berarti dalam memahami dan menyusun penyelesaiannya.

Kompetensi utama dan pendukung telah disajikan secara jelas sehingga mahasiswa dapat mengetahui kompetensi apa saja yang harus dicapai selama perkuliahan. Petunjuk penggunaan Modul dapat dipedomani dengan baik oleh mahasiswa sehingga pada saat perkuliahan tidak ditemukan kendala yang berarti seputar cara penggunaan Modul dalam pembelajaran. Secara visual, penulisan konsep, ide, istilah dan rumus yang ada pada Modul telah disajikan secara jelas. Hal ini terbukti dari tidak adanya pertanyaan mahasiswa seputar penulisan pada Modul. 
Penyajian materi telah membahasakan gagasan yang ingin dicapai sehingga mahasiswa tidak kesulitan dalam menangkap maksud yang ingin disampaikan. Penyajian materi juga telah memunculkan proses pembentukan dan pemahaman konsep karena disajikan ke dalam tahapan yang jelas dan terurut. Selain itu, Penyajian materi telah melibatkan mahasiswa secara aktif menemukan konsep secara mandiri. Gambar disajikan secara jelas dengan warna yang bervariasi sehingga dapat membantu mahasiswa dalam memahami konsep yang dipelajarinya. Modul telah menyajikan perumusan masalah yang akan menjadi fokus bagi mahasiswa dalam melakukan penemuan-penemuan.

Kalimat yang digunakan telah sesuai dengan kaidah bahasa Indonesia. Kalimat yang digunakan juga telah melibatkan kemampuan berfikir logis mahasiswa. Struktur kalimat telah sesuai dengan tingkat pemahaman mahasiswa. Bentuk dan ukuran huruf pada Modul telah sesuai dengan kapasitas keterbacaan mahasiswa. Selain itu, kalimat yang digunakan dalam penyajian Modul tidak memberikan makna ganda (ambigu).

\section{DAFTAR PUSTAKA}

Bridge, S., et al. (2010). "Rediscovering enterprise: developing appropriate university entrepreneurship education." Education + Training 52(8/9): 722-734.

Brown, A., et al. (2014). "Student engagement and learning: Case study of a new module for business undergraduates at Cass business school." Journal of Management Development 33(6): 603-619.

Emmitt, S. (2005). "Integrating teaching and research in an architectural technology undergraduate model." Journal of Engineering, Design and Technology 3(2): 164-179.

Fauzan, A., et al. (2013). "The development of an rme-based geometry course for Indonesian primary schools." Educational design research-Part B: Illustrative cases: $159-178$.

Gibbs, G. (2010). Dimensions of quality, Higher Education Academy York. 
Grattan, J., et al. (1998). "Student C\&IT skills development and the learning environment: evaluation and module evolution." Education + Training 40(8): 366-373.

Hodgkinson, L. (2000). "Benchmarking key skills using national standards: the open university experience." Benchmarking for Higher Education, Society for Research into Higher Education and Open University Press, Buckingham: 104114.

Kirby, D. (2007). "Changing the entrepreneurship education paradigm." Handbook of research in entrepreneurship education 1: 21-45.

Palihawadana, D. and G. Holmes (1999). "Modelling module evaluation in marketing education." Quality Assurance in Education 7(1): 41-46.

Pani, P. K. and P. Kishore (2016). "Absenteeism and performance in a quantitative module A quantile regression analysis." Journal of Applied Research in Higher Education 8(3): 376-389.

Purpose - There is growing evidence that learning is faster, measurably better and more productive in a classroom setting when a student attends classes regularly.

Tariq, V. N., et al. (2004). "Auditing and mapping key skills within university curricula." Quality Assurance in Education 12(2): 70-81.

Tiernan, P. (2016). "Enterprise education in initial teacher education in Ireland." Education + Training 58(7/8): 849-860. 